\title{
O aluguel como gestão da insegurança habitacional: possibilidades de securitização do direito à moradia
}

\author{
Rental as housing insecurity management: \\ possibilities for the securitization of the right to housing
}

Isadora de Andrade Guerreiro [I]

\section{Resumo}

Este artigo busca compreender novas dinâmicas imobiliárias locatícias nos territórios populares em São Paulo à luz das transformações macroestruturais que consolidaram a predominância da reprodução de capital fictício - que alteraram relações de trabalho, mecanismos de extração de renda e dão novos contornos ao papel estatal. A hipótese é a de que, com o incremento das relações de trabaIho "sem forma" na periferia do capitalismo, ganha relevância o papel do aluguel popular na conformação de um modo de vida marcado pela permanente insegurança habitacional. Tal dinâmica é incentivada e regulada por políticas públicas de direito à moradia que estão produzindo e vinculando tal insegurança à possibilidade de remuneração financeira, gerando ambiente propício à atuação de regimes privados de gestão territorial.

Palavras-chave: aluguel popular; securitização; informalidade; insegurança habitacional; auxílio aluguel.

\begin{abstract}
The article analyzes new rental real estate dynamics in popular territories located in São Paulo in light of macro-structural transformations that have consolidated the reproduction of fictitious capital, changing labor relations and income extraction mechanisms, and giving new contours to the state's role. The hypothesis is that, with the increase in informal labor relations on the periphery of capitalism, popular rental plays a relevant role in shaping a way of life marked by permanent housing insecurity. This dynamics is encouraged and regulated by housing policies that are producing and binding such insecurity to the possibility of financial remuneration, creating a favorable environment to the action of private regimes of territorial management.
\end{abstract}

Keywords: popular rental; securitization; informality; housing insecurity; rent benefit. 


\section{Introdução}

A reflexão sobre a relação entre desenvolvimento urbano local no Brasil e sua inserção no sistema econômico global atravessou, durante a década de 1970, a difícil questão de entender as contradições específicas de uma economia dependente (Marini, 2005; Frank, 1967), na qual a consolidação do território popular foi entendida como parte estrutural do processo de formação de relações de trabalho conformadas a transferências de valor no âmbito da divisão mundial do trabalho. Tais transferências de valor seriam apoiadas numa forma de reprodução social específica, na qual os trabaIhadores estariam submetidos a um modo de vida de custo rebaixado em relação aos salários pagos. Tal interpretação nos deu elementos para entender a dinâmica de ocupação de terras - e, mais recentemente na história, de edifícios vazios - das cidades brasileiras como parte de uma forma social específica, da qual faz parte o acesso à moradia e produção da cidade fora do mercado, autopromovida.

Mesmo acompanhando essa análise, parece-nos necessário atualizá-la ao olhar para a produção e acesso à habitação nos territórios populares nas suas relações com a dinâmica econômica recente, buscando entrever como a forma social própria à predominância da acumulação de capital fictício tem modulado a reprodução da vida de massas cada vez maiores de população, bem como seus territórios. As alterações no mundo do trabalho que, no centro do capitalismo, são denominadas "flexibilização da regulação trabalhista", no nosso caso, parecem cada vez mais ser a consolidação de um cotidiano de "trabalho sem forma" (Oliveira, 2003) que "termina por implodir as distinções entre tempo do trabalho e tempo do não trabalho, entre emprego e desemprego", tornando "inoperantes as diferenças entre o formal e o informal" (Telles, 2006, p. 174).

Assim, o contexto que na década de 1970 foi descrito como de predominância do trabalhador assalariado e proprietário (ou posseiro, o que não difere para os objetivos do argumento) de uma casa autoconstruída foi sendo substituído por emprego ${ }^{1}$ precário, "bicos" e empreendedorismo popular principalmente nos anos 2000 - a dita "viração" (ibid.) -, associados ao acesso à moradia via mercado popular. Dessa maneira, enquanto no primeiro período citado a predominância industrial e o assalariamento foram lastreados na relativa estabilidade habitacional permitida pela autopromoção da moradia, no período mais recente - principalmente na década de 2010 -, observamos que o avanço, também induzido pelo Estado, de aumento da incidência da propriedade sobre camadas de renda média baixa ou baixa fez parte de um processo de aumento da despossessão e submissão de grandes massas de população à total instabilidade do mercado imobiliário, principalmente locatício. 0 que estamos vendo nesse processo, talvez, possa ser entendido como uma nova fase adaptativa, na qual é importante uma gestão da espoliação, com outras camadas de subsunção.

Procuraremos, neste artigo, entender como, na última década, no município de São Paulo, a ascensão de novas formas de aluguel popular transformou o território periférico autoconstruído, historicamente ligado às relações de trabalho assalariadas e que agora se adapta à acumulação flexível. Acompanhando essas mudanças, olharemos para como a política pública municipal participa desse processo, também alterando o lugar dos direitos sociais - como a moradia -, antes ligados à noção 
de cidadania, agora sendo direcionados à conformação de um cidadão-consumidor (Dardot e Laval, 2016). Nesses termos, veremos como a política de aluguel social desse centro metropolitano se transformou numa política de insegurança habitacional lastreada no aluguel popular, que está em vias de ser capturado e influenciado por dinâmicas financeiro-imobiliárias. Procuraremos mostrar que tal processo, por necessitar de formas centralizadas e controladas de fluxos no território, tem conformado, nessa cidade, novos regimes privados de gestão de populações, que alteram as anteriores relações comunitárias ligadas à autoconstrução e à formação da classe trabalhadora assalariada. 0 incremento da gestão nas relações entre Estado, mercado privado e dinâmicas populares beneficia-se, nos termos que aqui se apresenta, de um novo regime de historicida$\mathrm{de}^{2}$ no qual a expectativa futura por direitos sociais, como a moradia, nunca alcançados, é realizada de maneira urgente, no presente, porém de maneira descarnada, por meio de remuneração financeira e de diversos tipos de violência local e estatal.

As hipóteses aqui formuladas derivam de revisão bibliográfica, coleta de dados, entrevistas semiestruturadas individuais e coletivas com beneficiários, agentes de mercado e poder público, além de trabalho de campo em alguns territórios populares do município de São Paulo afetados pela política pública de aluguel temporário. Tanto a localização quanto a identidade dos entrevistados em campo serão preservadas para evitar retaliações, por meio da omissão de seus nomes ou adoção de nomes fictícios, a depender do caso.

\section{Da autoconstrução à "viração": o território popular sob dominância financeira}

A discussão travada no Cebrap (Centro Brasileiro de Análise e Planejamento) e na FAUUSP (Faculdade de Arquitetura e Urbanismo da Universidade de São Paulo), na década de 1970, informa-nos sobre os locais de moradia dos trabalhadores de São Paulo como extensões horizontais, muitas vezes próximas a locais de grande concentração de trabalho (plantas fabris no $A B C$ ou canteiros de grandes obras, por exemplo), com casas autoconstruídas principalmente para uso direto da família como moradia. Há predominância da necessidade básica imediata, suprida por meio de redes de solidariedade na produção da casa e uso da infraestrutura urbana oficial de maneira escalar, com várias formas de ilegalidade. Esse contexto de produção do espaço construiu também a subjetivação e a figuração social do trabalhador (Feltran, 2011), que depende de sua criatividade para transformar a realidade ao seu redor e da solidariedade, estabilidade e acúmulo do trabalho coletivo - comunitário e/ou familiar como referência e mediação social.

As análises desses autores vinculados ao Cebrap e à FAUUSP na década de 1970 - em particular Lúcio Kowarick, Francisco de Oliveira e Ermínia Maricato - tiveram o mérito de superar o entendimento de uma anterior escola "dualista", para a qual tais assentamentos eram expressão de um atraso do país a ser extinto pela crescente industrialização. Tais autores citados identificaram, criticando tal visão 
dual, uma estreita conexão entre a forma específica de desenvolvimento nacional e a falta de condições de reprodução da vida dos trabaIhadores: tal processo seria mais bem descrito pela espoliação urbana (Kowarick, 1979), na qual a autopromoção das condições de sobrevivência representaria transferências de valor importantes para o fundo de acumulação do capital industrial local (Oliveira, 2003).

Oliveira (ibid.), em estudo clássico que embasou grande parte da reflexão sobre o urbanismo brasileiro após a década de 1970, parte do dado aparentemente contraditório observado em campo de que os moradores dessas áreas periféricas se declaravam, em sua maior parte, proprietários de suas moradias autoconstruídas, embora não tivessem um título de propriedade. De acordo com ele, as práticas populares de autopromoção da reprodução da vida - presentes na saúde, na alimentação, no vestuário, mas, sobretudo, na habitação a partir da autoconstrução - retirariam custos do capital, constituindo seu fundo de acumulação permanente, baseado num estrutural baixo salário, que não cobriria as necessidades básicas do trabalhador. Dessa maneira, tais práticas, amplamente difundidas e que conformaram as cidades brasileiras, seriam corresponsáveis pelo rebaixamento salarial e pelo fundamento histórico e social da exploração de sua mão de obra.

Essa noção de Oliveira da autoconstrução como resposta autônoma e privada à necessidade de moradia própria da família que a promoveu $^{3}$ nos parece bastante questionável, na medida em que o aluguel e as transações imobiliárias populares já estavam presentes nas análises da época (Bonduki e Rolnik, 1982). Atualmente, no entanto, o aspecto de mercadoria da moradia autoconstruída é inescapável e cada vez mais predominante no território popular. Pesquisas da última década (Meyer et al., 2017; Abramo, 2009) demonstram que a produção dos territórios populares tem sido cada vez mais marcada pela dinâmica do mercado imobiliário popular (com participação importante do aluguel), tornando as noções de "informalidade", "precariedade" e "ilegalidade" insuficientes, tornando-se inoperantes. Tudo isso marcado pela transformação de uma "sociedade de baixos salários" numa sociedade não organizada mais hegemonicamente pela relação salarial, fato que altera objetivamente e subjetivamente a noção de "trabalhador" (Feltran, 2011).

Telles (2006) também refletiu sobre a permeabilidade dessas categorias, ao analisar as relações entre as alterações no mundo do trabalho e as práticas urbanas populares que as acompanham de maneira específica, localmente, dando relevo às ambivalências produzidas pela intermitência e multiplicidade da chamada "viração". É necessário, aqui, observar que as formas de "viração" no mundo do trabalho são acompanhadas por alterações similares nas formas de morar e de dispor da terra e das edificações nos territórios populares. Se antes, na tese de Oliveira, a posse ilegal da moradia autoconstruída fazia parte das transferências de valor internas à dinâmica da sociedade salarial, é necessário olhar agora para o aluguel - nas suas mais diversas formas como um dos mecanismos que operam a "viração" do urbano, caracterizado por um estado de "transitoriedade permanente" como decorrência de uma conjuntura institucionalizada de insegurança habitacional, lastreada em remoções (Rolnik, 2019). 


\section{0 aluguel popular como substituto do aluguel social}

A hipótese de desenvolvimento capitalista nacional lastreada no fundo de reprodução do trabalhador coloca uma especificidade local que difere daquela encontrada na Europa, na qual, ainda segundo Oliveira (1988), seria o fundo público aquele que teria, em grande parte, ocupado o papel de conformador do fundo de acumulação do capital na forma de "salários indiretos", por meio de políticas públicas que efetivariam direitos sociais. ${ }^{4} \mathrm{Al}$ mejando essa forma de desenvolvimento é que vai se consolidar a defesa da democracia brasileira em meados da década de 1980, quando os direitos sociais são defendidos por setores progressistas como forma de "realinhamento" dos rumos do desenvolvimento, e o Estado - através do investimento direto do fundo público - proveria, por meio de serviços públicos, aquilo que estava sendo autopromovido pelos trabalhadores, alterando o ciclo de desenvolvimento do País.

A efetivação da habitação como direito social, que tem diversas maneiras de concretização, mas, entre elas, sua transformação em serviço por meio do aluguel em parque edilício público, tal qual foi implantada no welfare state europeu, sempre foi parte das defesas dos urbanistas - o chamado aluguel social, que liberaria a remuneração do trabalhador para o consumo com estabilidade na moradia. No caso brasileiro, a implantação de tal política pública poderia ter o mesmo papel que na Europa, colaborando para uma mudança no padrão de desenvolvimento que se afastasse da lógica espoliativa baseada na posse ilegal da terra pelos trabalhadores? Transformar a moradia em salário indireto por meio do aluguel colaboraria para a construção dos tais controles institucionais almejados? A resposta afirmativa a essas questões fez o tema crescer de importância nos anos 2000, tendo sido implantado o Programa de Locação Social (em parque edilício próprio), no município de São Paulo na gestão de Marta Suplicy (PT, 20012004); que, embora pequeno, instalou o tema do aluguel na política habitacional municipal, que tem sido cada vez mais retomado e aparece com destaque no Plano Municipal de Habitação $0^{5}$ (PMH) de 2016, por meio de uma série de outras modalidades.

0 que se viu na prática, porém, foi a implantação, no mesmo período, de programa de aluguel social bastante mais flexível: uma complementação pecuniária mensal à locação habitacional privada, concedida pelo município para famílias removidas por obras, vítimas de desastre, ocupantes de áreas de risco ou de extrema vulnerabilidade - o hoje chamado Auxílio Aluguel. ${ }^{6}$ Não há nenhum controle do poder público sobre a habitação final locada pelos beneficiários, que, na observação de campo e nos depoimentos de gestores públicos, encontra-se apenas no mercado popular: ocupações, áreas de risco, áreas não legalizadas, muitas vezes não urbanizadas, de poucos cômodos em relação às necessidades familiares, muitas vezes de má construção ou em zonas alagadiças, com restrições a crianças e animais, sem segurança jurídica contratual e com exigências de caução das mais diversas, além de despesas de água e luz antes inexistentes na autoconstrução (nenhuma delas cobertas pelo programa público, de $\mathrm{R} \$ 400$, que mal cobre o preço do aluguel de barracos insalubres na extrema periferia, como alguns visitados para esta pesquisa). 
Tal programa ganhou um tamanho extremamente relevante, principalmente depois de 2011, girando hoje em torno de 27 mil benefí$\operatorname{cios}^{7}$ (tendo chegado a 30 mil em 2016), com parte de famílias atualmente inscritas e aguardando a habitação definitiva desde 2008. Algo muito mais relevante do que as cerca de 900 unidades habitacionais próprias que o município mantém em aluguel social no Programa Locação Social. Vemos aqui que o aluguel social, dentro da perspectiva acima descrita do direito social, na verdade concretizou uma dinâmica de "salário indireto" ligada ao aluguel popular. Diferentemente da estabilidade preconizada pelo acesso ao direito social, a política pública na qual se insere o Auxílio Aluguel cria um quadro de insegurança habitacional, ligado a modos de vida em transitoriedade permanente (Rolnik, 2019): ele é usado como dispositivo de remoção associada à submissão ao mercado imobiliário popular, que induz, muitas vezes de maneira violenta, a prioridade da família a se inverter - da comida para o aluguel e concessionárias de serviços públicos. Isso é exemplificado neste depoimento, ${ }^{8}$ que relativiza a melhora nas condições de moradia após remoção e Auxílio Aluguel:

A melhoria depende... aqui é melhor porque é de tijolo. Mas eu sinto muita falta de lá. Sinto falta porque você tira de onde não tem, tem que inteirar o dinheiro do aluguel. Que nem mês passado mesmo, a gente teve que se virar para juntar o dinheiro do aluguel. Que R\$400 não dá pra pagar um aluguel. Porque não tem mais casa de $R \$ 400$. A maioria é $R \$ 500$, $R \$ 600, R \$ 700$. Eu acho que mil vezes onde a gente tava. Mil vezes a gente tava felizes lá. A gente não estaria passando por sufoco. A gente tira do feijão para botar no aluguel. [...] Aqui é seguro porque é de tijolo e na hora da chuva a gente não tem que passar pelo que passava, mas, sinceramente, eu preferia estar lá.

Dessa maneira, vemos que há uma transformação do quadro no qual a formação da classe trabalhadora assalariada, em país dependente, era lastreada na estabilidade relativa proporcionada pela autoconstrução e para a qual se almejava a produção pública de habitação com participação relevante de aluguel social. No outro quadro, atual, a formação da nova classe trabalhadora, forjada para a "viração", é lastreada na insegurança habitacional formada pela política pública que a remove e a lança ao aluguel popular.

Assim, a era das políticas públicas, ao menos em São Paulo, demonstrou que o acesso aos fundos públicos, antes de alterar o ciclo de desenvolvimento baseado na espoliação, ao inserir elementos do que poderia ser um "salário indireto", na verdade, subsumiu ao mercado modos de vida antes possíveis pelo que Oliveira chamava de "não mercadoria" (a casa autoconstruída, no seu exemplo). E, ao fazer isso, não criou a classe trabalhadora assalariada clássica, pois os bens e serviços que ela pode acessar permanecem sendo aqueles do mercado popular, com diversos níveis de informalidade, ilegalidade e barreiras sociopolíticas das mais diversas ordens. Conformou-se um aumento da insegurança social, não uma diminuição, como no caso europeu. Não nos parece ser uma mudança de rumos, um projeto fracassado, mas a adequação do desenvolvimento dependente de uma nova etapa, na qual o acesso ao mercado mediado pelas políticas públicas passa pelo amoldamento e dependência da legalidade ao hibridismo das dinâmicas populares - e não o contrário, como talvez se imaginasse possível. 


\section{Mercado imobiliário nos territórios populares}

Dados da Pesquisa Nacional por Amostra de Domicílios - PNAD Contínua do IBGE dão conta de que a porcentagem de domicílios alugados na Região Metropolitana de São Paulo (RMSP), em 2001, era de 16\% e sobe, em 2018, para $23 \%$, um aumento de $7 \%$ de participação, o que corresponde a um crescimento de cerca de $43 \%$ no período. Essas porcentagens não têm variação relevante nas diferentes faixas de renda, o que demonstra que o aluguel passou a ser uma realidade também para a população de baixa renda, diferentemente da década de 1970. Tal cenário é acompanhado pelo aumento do preço do aluguel numa variação acima e descolada da dinâmica da inflação entre 2010 e 2015, movimento ainda mais acentuado e estendido nos imóveis de 1 dormitório, que atualmente têm valorização muito acima da inflação e de outras categorias de imóveis (Gráfico 1). Isso certamente colaborou para uma mudança no perfil do déficit habitacional na RMSP no mesmo período (Gráfico 2), quando o ônus excessivo de aluguel teve um salto relevante acima dos outros fatores. Dados do Labcidade da FAUUSP ${ }^{9}$ mostram que nos últimos cinco anos foi executada cerca de $140 \mathrm{mil}$ processos de despejos relacionados ao aluguel na RMSP (com decisão já deferida).

Tais dados e pesquisas de campo nos mostram que há uma mudança na dinâmica imobiliária popular nos últimos 10 anos na RMSP, que tem se aproximado mais daquela típica de mercado, independente da legalidade da propriedade. Em territórios populares mais consolidados, o desenvolvimento geracional e financeiro das famílias, somado à escassez de terras urbanas disponíveis, anos de investimentos públicos e novas dinâmicas sociais relacionadas à gestão territorial levam a um novo fenômeno de verticalização. ${ }^{10}$

Gráfico 1 - Variação percentual mensal do Índice Fipezap para Locação Residencial (Município de São Paulo) e do IPCA

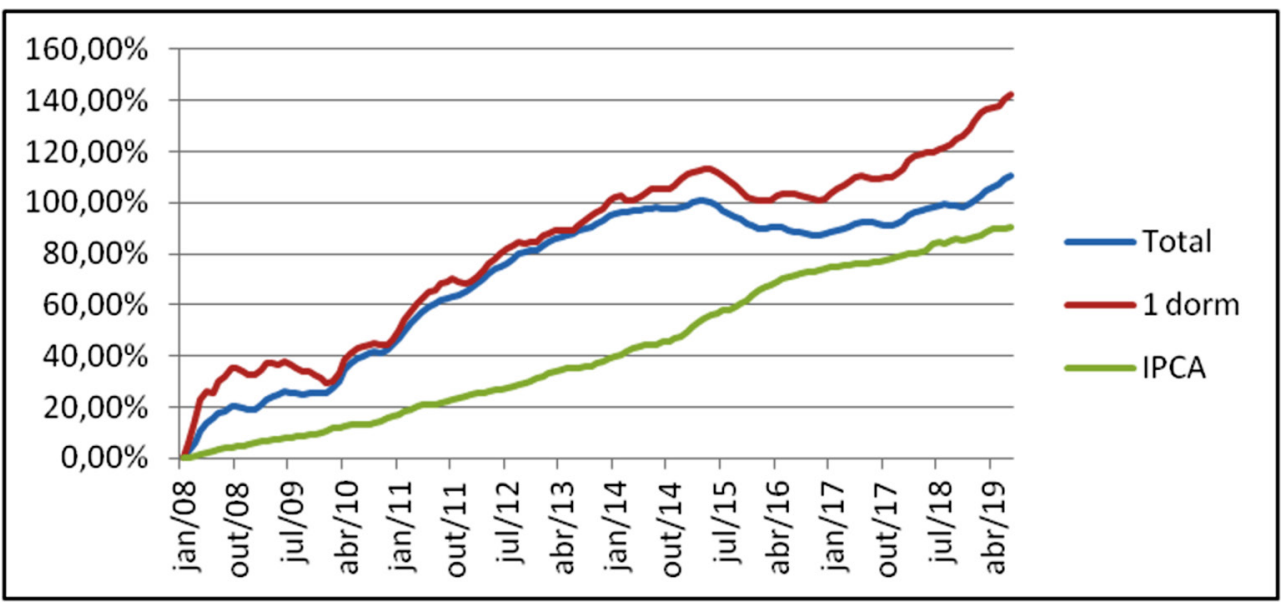

Fonte: elaboração própria com dados imobiliários para locação residencial em São Paulo da Fipe e da inflação via IBGE. 
Gráfico 2 - Perfil do déficit habitacional da RMSP

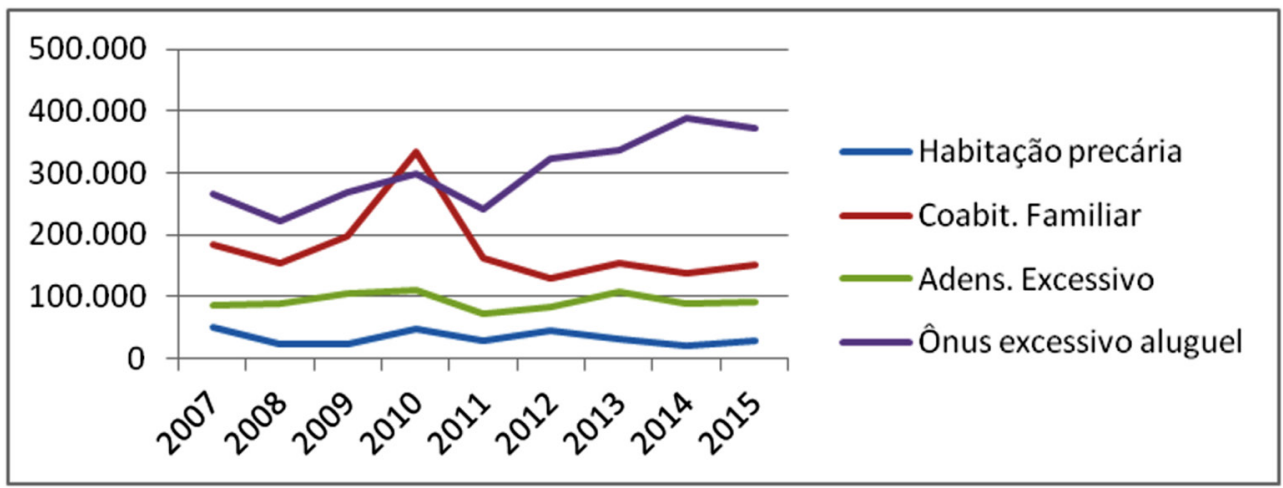

Fonte: elaboração própria com dados da Fundação João Pinheiro, de 2007-2015.

Em 2017, pesquisa desenvolvida na FAU-USP, intitulada "Mercado imobiliário residencial em Paraisópolis: 0 que mudou nos últimos dez anos?", 11 aponta para algumas características importantes desse processo. Embora tenha se detido em apenas um território (uma das maiores favelas de São Paulo, com cerca de 17 mil domicílios), é bastante relevante no contexto geral das Regiões Metropolitanas do Brasil, tendo em vista a inclusão da pesquisa em um grupo maior de cidades e pesquisadores que, em 2006, fez um levantamento do mercado informal em 8 regiões do País. ${ }^{12}$ Um dos dados mais relevantes levantados foi justamente esse aspecto da verticalização que, em dez anos, passou de $4 \%$ para $31 \%$ dos domicílios do território. Mais do que a dinâmica de crescimento familiar, os pesquisadores detectaram uma grande produção para venda e aluguel, cuja maioria de promotores (54\%) era moradores do próprio território e tinha mais de um imóvel. As tipologias direcionadas ao mercado de locação, em relação ao levantamento feito dez anos antes, tiveram diminuição de área construída e de número de cômodos, sendo sua maioria (70\%) de apenas um (tipo quitinete). Além disso, o mercado foi avaliado como de grande rentabilidade em comparação com o setor imobiliário legal, tendo apresentado uma valorização de mais de $300 \%$ no valor da terra no período e Rental Yield ${ }^{13}$ superior em quase $200 \%$ em relação ao mercado formal. ${ }^{14}$

Para além dos números, a pesquisa detectou uma mudança na dinâmica dos agentes e estratégias imobiliárias. Mais da metade dos imóveis colocados no mercado eram intermediados por corretores, que buscavam maior formalidade contratual - ainda que isso não tenha a ver com a regularidade do imóvel, e que, portanto, não signifique interferência do poder judiciário no território que, vamos ver adiante, tem seus próprios processos de regulação. Apareceu, também, a figura da incorporação (não observada anteriormente): terrenos com baixa ocupação sendo comprados para demolição do imóvel e construção mais 
vertical, para aluguel. De maneira geral, havia controle centralizado sobre terras ainda vazias ou em disputa, principalmente áreas de risco: os pesquisadores relatam a presença de agentes reguladores locais que têm domínio sobre a negociação dessas áreas com a prefeitura e com novos ocupantes, numa métrica mercantil na qual incidem recursos privados (em bens ou dinheiro) e públicos, como o Auxílio Aluguel - que atua na relação entre a remoção de famílias e o mercado imobiliário local. Essa dinâmica, disseminada nos territórios populares da metrópole, pode ser observada neste depoimento (morador de outra área): $:^{15}$

Eu morava em Itapecerica, longe pra caramba. Como era muito longe pra serviço, eu achei esse barraco, aí falei: "ah, vou morar no barraco". Comprei um som: o cara tava querendo o som. Falou: "cê me dá o som, eu te dou o barraco". E eu troquei pelo barraco. Foi na época que "saiu", 16 eu peguei ${ }^{17} R \$ 8$ mil. $R \$ 8$ mil não dava pra fazer nada. Aí o que foi que eu fiz? "Saiu" no [terreno] particular, eu comprei no [terreno] da prefeitura. ${ }^{18}$ Eu paguei $R \$ 4$ mil pro cara. "É R\$S4 mil, se quiser". Aqui o pessoal tá vendendo [atualmente] barraco de até $R \$ 10 \mathrm{mil}$. Barraco, em qualquer canto... tem terreno até de $R S$ 20mil. [É por causa do terreno? Como funciona?] Eu faço meu barraco e vendo pra você. Pra quem não conhece, chegar assim na comunidade e fazer um barraco é difícil. Tem que ter um "conhecimento". Funciona assim: “Aqui é meu e já era. Você quer morar? Então, você paga". Tem que pagar. [Pela terra, né?] É, a terra que não é sua, e não é nem do outro. Mas tem que pagar pra morar, pra fazer [o barraco]. Aí eu paguei $R \$ 4$ mil, fiquei morando um ano, foi quando a prefeitura veio e tirou. Isso foi 2009, e eu comecei a receber o Auxílio.
Tais fenômenos não podem ser entendidos, portanto, sem a interferência da política pública: a pesquisa em Paraisópolis referida acima levantou os investimentos em obras e urbanização e deu especial importância para o instrumento do Auxílio Aluguel concedido para famílias originárias daquele território, que representam cerca de $26 \%$ do total de domicílios. A alta porcentagem desse benefício pode ter incentivado o crescimento de ofertas de aluguel e, também, balizado os seus valores: enquanto o valor médio da locação ali é de $\mathrm{R} \$ 550$, o Auxílio Aluguel é de $\mathrm{R} \$ 400$, definindo um limite mínimo para esse mercado. Essa dinâmica, na verdade, pode ser extrapolada em relação a esse território: dados da PNAD Contínua mostram que, depois de 2011, ano em que essa política ganha maior expressão, os alugueis das faixas de renda até 3 salários mínimos em toda a RMSP são pressionados para valores em sua maioria acima desse mínimo (justamente entre $R \$ 500$ e $R \$ 600$ ), ganhando proporções maiores do que a família poderia assumir (acima de 30\% da renda familiar, quando entra no patamar de déficit habitacional por ônus excessivo de aluguel, sem considerar as despesas da legalidade da casa, como água e luz).

A nova dinâmica fundiária instalada parece ter origem no fato de que as terras foram ficando cada vez mais escassas e, com o Programa Minha Casa Minha Vida (que começa a entregar unidades a partir justamente de 2011), até mesmo aquelas piores e mais distantes passaram a ter preço que antes não tinham, num avanço de formas de renda absoluta da terra (Guerreiro, 2017). Houve uma intensificação do uso da terra em toda a RMSP, aumentando a ocorrência e a tensão de novas ocupações, em especial em áreas de risco ou 
de proteção ambiental. Com o aumento do valor e da extensão da precificação da terra, o domínio sobre ela também teve sua dinâmica alterada, acompanhando a consolidação de regimes privados locais de gestão territorial que implementaram restrições ao seu acesso que, na prática, extinguiram a antiga prática popular de chegar numa localidade e autoconstruir de maneira autônoma. Para tanto, atualmente, é necessária a submissão ao regime territorial instalado, cuja entrada pode ser por meio de trocas financeiras, redes de apoio, trocas políticas, etc. Na prática, o acesso à moradia passou a ser cada vez mais realizado por meio do mercado - seja através de compra e venda, seja através do aluguel, independentemente de a origem da posse da terra ser legal ou não. Mesmo as ocupações organizadas de terrenos e imóveis vazios ganharam novas dinâmicas no último período, na medida em que fazem parte desse contexto modulado pela combinação entre regimes privados territoriais e sua legitimidade política balizada pela hegemonia de certas políticas públicas que amoldaram o direito à moradia à sua face privada, individual - como é o caso do Auxílio Aluguel citado.

Tal política pública é baseada na existência do aluguel informal no mercado popular privado, utilizando-o como resposta ao direito à moradia de famílias principalmente removidas de áreas autoconstruídas - a solução dos trabalhadores cujo custo da moradia não está presente na sua remuneração. Um cotidiano de remoções foi assim facilitado e possível, pois mediado pelo mecanismo do Auxílio Aluguel, que deu amparo legal e alternativa de moradia aos removidos - ainda que a sua solução concreta seja informal e precária, o contrato (do benefício) é formal, criando um campo cinzento no arcabouço jurídico dos direitos. Além disso, esse processo que se instalou em São Paulo na última década colocou em andamento uma conformação do modo de vida das famílias ao mercado imobiliário popular de larga escala. Essa realidade está presente na fala de alguns entrevistados, exemplificada neste depoimento: ${ }^{19}$

\begin{abstract}
Ah, isso é uma coisa normal, todo mundo tem que pagar um dia, né? [...] Eu até fiquei sabendo de outra área de ocupação, mas não quis ir não. Eu preferi ficar aqui mesmo. [Não queria ter que passar por tudo aquilo de novo?] Não, tudo de novo não! Cê é loco? Vê toda aquela destruição de novo, tudo aqueles negócios feios... não! Aqui tá suave. Cê é loco... mó coisa horrível. Tô tranquilo, nunca mais quero passar por isso na minha vida. Se tiver que pagar aqui... daí o Auxílio ajuda também. Mas, se não, se brecar, ${ }^{20}$ é pegar uns bicos aí, fazer o quê? Tem que pagar aluguel.
\end{abstract}

Percebe-se que há, portanto, um amoldamento do modo de vida popular antes conformado pela autoconstrução em ocupação de terra livre a outro, conformado ao mercado de aluguel possibilitado pela política pública que remove e insere as famílias nas relações privadas de aluguel, que também são parte da necessidade dos "bicos" permanentes. É nesse sentido que entendemos essa dinâmica como própria de uma gestão de populações (Foucault, 2010), que envolve a necessidade de consolidação de uma conjuntura específica de insegurança habitacional, que pode ser captada financeiramente por relações público-privadas. 


\section{Parceria público-privada- - popular por meio do aluguel}

Um passo mais robusto na direção de transformar o aluguel num mecanismo de gestão de populações deve, necessariamente, envolver uma parceria entre Estado e mercado, com alguma centralização de capital - e não agentes privados de dispersão quase individual, como é o mercado popular. Uma possibilidade que já vem sendo discutida no município de São Paulo é a intermediação de imobiliárias licitadas e cadastradas pela prefeitura para a locação subsidiada em parque privado (tal qual é o Auxílio Aluguel hoje), o que geraria mais formalidade, condições de habitabilidade e controle de gestão, colaborando, inclusive, para diminuir o ciclo de ocupações. O Auxílio Aluguel poderia ser repassado diretamente para a imobiliária, que colaboraria com a gestão do programa junto ao beneficiário, que também contaria com mais segurança.

O modelo que está sendo analisado é inspirado naquele desenvolvido atualmente pela startup Alpop, ${ }^{21}$ uma imobiliária especializada em locação popular (de aluguéis de até $\mathrm{R} \$ 1.700)$, que funciona por meio de plataforma digital. Seus proprietários são uma sociedade entre a do-tank Urbem, ${ }^{22}$ a empresa de tecnologia Caiena, ${ }^{23}$ e o escritório de advocacia Arap Nishi \& Uyeda. ${ }^{24}$ A Alpop não exige fiador do locatário nem caução ou comprovação de renda e não utiliza o cadastro do Serasa, mas apenas uma pesquisa simples via CPF, que gera um score próprio para avaliação de risco de crédito dessa faixa de renda, que pode ter muitas outras aplicações de mercado. A empresa garante ao proprietário o pagamento mensal do aluguel mesmo que ele não o faça, também se responsabilizando por eventuais despejos e cobrando taxas simbólicas para fazer a manutenção do imóvel.

O sistema de captação de imóveis é feito a partir de um "método ágil de gestão" denominado scrum, que envolve a articulação entre busca de informações em campo (bairro a bairro) e constituição de relações com pessoas do local, com o processamento de dados direcionados à construção de softwares. Sua finalidade é criar capacidade gerencial direcionada à população de baixa renda por meio da inteligência artificial integrada a "ações de impacto de cidadania". A construção do score vai nessa direção, mas potencializa-se com a articulação dele aos modos de uso da cidade, que tem informações georreferenciadas ligadas ao mercado imobiliário popular que pretendem alcançar um critério de valoração e precificação de imóveis hoje fora da institucionalidade. Uma relação entre "experiência" e extração analítica de dados. Segundo Lilian Veltman, coordenadora da Alpop:

A gente faz tudo em termos de experiência. Tudo monitorado. Então a gente faz a cada 20 dias uma experiência e identifica o que aconteceu. [O que é uma "experiência"?] Experiência é o que a gente chama de "apontador de imóveis": o pessoal que mora no entorno que vai indicar um imóvel para a plataforma. Então a gente já contratou pessoas - que não são corretores - que vão se relacionar. Daí pode ser com porteiros, com o cara da padaria, da loja de material de construção (isso muito, a gente visualizou muito a questão do material de construção). [...] E o que a gente percebeu é que existem bairros com uma população mais 
tradicional em que isso funciona - isso funcionou e a gente teve resultados com esse contato presencial através de um agente que mobilizou. ${ }^{25}$

Nesse sentido, a Caiena aparece como sócia principal do negócio, criadora do Fundo de Impacto Social Caju, que financia a Alpop. Os Fundos de Impacto Social constituem-se geralmente por meio de Fundos de Investimento em Participações (FIPs), regulados pela Comissão de Valores Imobiliários (CVM), que normalmente envolvem alto investimento inicial e longo tempo de retorno (cerca de 10 anos). O chamado "impacto positivo" é uma estratégia empresarial que vem no bojo do avanço do empreendedorismo, no qual tais fundos são utilizados para desenvolvimento de startups que tenham justificativa social. São muito usados na área de educação e pequenos negócios, mas têm expandido suas atividades para todas as esferas dos direitos sociais, criando uma forma nova de gestão que configura também uma nova forma de Estado, no qual as fronteiras entre público e privado se tornam difíceis de delinear.

Embora no Brasil ainda seja pequeno, o mercado de Impacto Social tem ganhado expressividade no exterior ${ }^{26}$ principalmente por meio dos Títulos de Impacto Social (em inglês Social Impact Bonds ou SIBs), que podem se configurar como debêntures (títulos de dívida) ou Certificados de Recebíveis, atrelados a causas sociais. São formas de captação de recursos no mercado financeiro utilizadas por empresas e por governos - nesse caso, com um volume muito maior de recursos e garantias. Isso faz com que a justificativa social das empresas, na verdade, seja uma forma de se gabaritar para a prestação de serviços estatais, captando fundos públicos para o mercado financeiro.
No Brasil, na área da habitação, temos notícia do Programa Vivenda e do Projeto Bem Viver Centro ligados a esse mercado. 0 primeiro foi estruturado pela startup Artemísia junto à gestora Dín4mo e uma das maiores securitizadoras do País, o Grupo Gaia, promovendo reformas através de kits em moradias populares. Já o segundo tem por trás a empresa Magik JC, que passa por um processo de transformação de construtora tradicional para "BCorp" (Benefit Corporation) - uma certificação ligada ao mercado de Impacto Social -, com uma proposta de construção para aluguel social na área central de São Paulo. Nenhum desses negócios se conecta hoje com o poder público, embora tal conexão pudesse fazê-los crescer enormemente - o que os faz se articularem em torno de mudanças legislativas, como veremos a seguir.

A Alpop foi usada aqui como exemplo na medida em que acreditamos que seu modelo de negócios seja aquele que mais se relaciona com as potencialidades financeiras do Auxílio Aluguel. Ela configura-se hoje apenas como uma imobiliária de plataforma virtual, cujo negócio não se relaciona com a política pública, apenas com o mercado popular. No entanto, ela apoia tal negócio no pressuposto de dar alguma formalidade a tal mercado - por meio do contrato de aluguel, não pela regularização fundiária. Dessa maneira, encontra-se com o objetivo também do poder público, cuja política de aluguel temporário sem controle para a mesma população tem alcançado certo limite na equação de custo-benefício. Um lado não depende atualmente do outro, mas o encontro dos dois pode promover alavancagem de possibilidades, hoje apenas potenciais tanto de rendimentos financeiros quanto de capacidade gerencial na produção do espaço pelo poder público. Esse possível encontro - hoje 
mais provável, como veremos a seguir - leva a uma forma de captar o Auxílio Aluguel pelo mercado que aponta para outras questões, que se relacionam com as potencialidades da institucionalização das práticas imobiliárias das diversas formas de morar populares, cuja capilaridade social é muito maior do que as possibilidades do setor imobiliário formal e exigem relações diretas com suas lideranças, gestores ou domínios locais - como visto na fala da coordenadora da Alpop acima.

A intermediação entre Estado e população despossuída realizada por intermediários ligados ao mercado de Impacto Social permite novas formas de política pública - cujo alcance ainda não temos dimensão - baseadas no paradigma da gestão da insegurança habitacional, e não na efetivação do direito por meio da realização da mercadoria casa ou da locação em parque público. É uma efetivação transitória, cuja solução por meio do mercado popular "no varejo" pode parecer precária, mas, na verdade, pode colocar em andamento processos institucionalizados pela gestão contratual, que podem acionar valorização financeira na medida em que operacionalizam dispositivos de centralização de rendas dispersas - por meio de agentes locais, instrumentos jurídicos, aporte financeiro e tecnologia da informação -, e pode as garantir através do fundo público, como se mostra a seguir.

De maneira mais efetiva, há tramitação na Câmara dos Vereadores de São Paulo de um projeto de lei (PL 258/2016) que coloca em andamento essas possibilidades e ainda outras de relação do poder público com o mercado por meio do aluguel de habitação social. Foi aprovado e teve decretada lei recentemente (19 de dezembro de 2019), porém em seguida vetada ${ }^{27}$ integralmente pelo prefeito Bruno
Covas (PSDB) - fato que demonstra como tais transformações estão em disputa, ainda sem desenlace certo. O PL cria um Fundo Gestor e Garantidor ligado à Secretaria da Habitação, porém gerido por agente privado, que seria o locatário dos contratos de aluguel com demanda pública no mercado privado (que inclui largamente o popular). Esse dispositivo retira o pagamento direto ao beneficiário do atual Auxílio Aluguel, transformando-o em um voucher pago para o locador - que pode construir imóveis para aluguel social de maneira incentivada (incentivos tributários, fiscais e urbanísticos) ou credenciar carteira própria (como é o caso de imobiliárias como a Alpop). O locador, ainda segundo o $\mathrm{PL}$, poderá emitir papéis a mercado por meio de Fundos Imobiliários ou Certificado de Recebíveis Imobiliários (CRI), lastreados nos recebíveis de aluguel do Fundo Gestor.

Esta seria a possibilidade de relação, por exemplo, entre imobiliárias, como a Alpop ou a construtora Magik JC, e a política pública de moradia, que quer fugir da antiga necessidade de provisão habitacional em parque público. Segundo o ex-secretário de Habitação, Fernando Chucre, questionado em relação à Alpop:

Até a proposta para eles [Alpop] foi a gente fazer um convênio com a secretaria de habitação, oferecendo para essas famílias que estão com o Auxílio Aluguel a possibilidade de elas entrarem no mercado formal. [E o gerenciamento disso ficaria mais controlado?] Sim, muito mais controlado. E entra na discussão do déficit geral: se eu não tenho financiamento para produzir o imóvel para "vender" (vamos chamar assim), ou para destinar para fins de baixa renda, o que me faz crer que eu vou ter para fazer locação social? Porque o recurso para você gerar o imóvel é praticamente o mesmo - e a 
gente criou várias ferramentas distintas com a iniciativa privada participandomas em tese, se você pensar assim, aqui você tem que produzir ou adquirir um imóvel se for no modelo público, para poder ou dar, ou transferir a propriedade ou manter a propriedade do Estado e operar como Locação Social. A diferença é que tem um outro pacote inteiro aqui que eu não tenho que desapropriar! O cara vem e fala "eu aporto o imóvel". ${ }^{28}$

\section{Enlace: os regimes privados de gestão territorial}

Na sexta-feira deu enchente: eu passei só um dia no barraco! Quando a água baixou ficou só os paus em pé, porque a enchente levou tudo, tudo. Levou. Aí cabou tudo e eu não abaixei a cabeça, não. Fui na Telhanorte, comprei umas outras madeiras e coloquei no barraco tudo de novo. Vou ficar aqui! Quando foi outro dia a mulher da prefeitura passou lá muito revoltada comigo, me xingou muito, também xinguei ela, então ela foi e falou com o Ednei. O Ednei falou pra ela: "ou você dá Auxílio Aluguel para a Cleide, ou volta todo mundo na beira do rio de novo". E aí eles me deram e eu fiquei foi feliz, é pouco mas quebra o galho. Eu só ponho mais $R \$ 200$ e vou empurrando com a barriga, né? Assim vai, até o dia que Deus quiser. ${ }^{29}$

A trajetória de Cleide nos traz um exemplo típico dos processos que estamos analisando. Da "viração" entre o aluguel subsidiado, o desastre urbano em área de risco, a remoção e a autoconstrução até a gestão da instabilidade "até o dia que Deus quiser" mediada pela parceria entre poder público e forças sociais de gestão privada local. Em entrevistas realizadas em comunidades removidas, merece atenção o fato de que as famílias beneficiadas com o Auxílio Aluguel, em sua maioria, acessaram a locação residencial pela primeira vez na vida por meio da política pública e, sem ela, não teriam condições de permanecer nesse mercado - cuja sujeição aos regimes locais de poder é maior, por conta da instabilidade gerada.

Ednei, no caso, é a liderança comunitária, cuja posição social e política na comunidade foi construída pelo entrelaçamento das suas ações em diversos níveis: organização comunitária interna, negociação externa com os bairros ricos vizinhos, negociação com o poder público, articulação de redes de solidariedade e trabalho do terceiro setor na comunidade, regulação do comércio lícito e ilícito, regulação territorial, entre muitas outras práticas cujo limite de legalidade e estabilidade de definições é uma categoria e um método inoperantes para o entendimento. "Ednei" - ou a nova face da liderança comunitária ${ }^{30}$ - é utilizado como instrumento, como meio, para que a política pública funcionalize, a seu favor, mercados imobiliários populares. Ele perpassa todas as relações, das que parecem mais individuais até as negociações com o poder público (como vimos na fala de Cleide): ele é um agente de gestão dessa população. É ele quem a prefeitura contata para chamar os beneficiários do Auxílio Aluguel sob sua alçada para reuniões sobre andamento do processo das moradias definitivas ou sobre recadastramento.

O Auxílio enquanto elo com o poder público, portanto, é elemento importante de uma dinâmica socioterritorial na qual ganha centralidade a relação de aluguel, na medida em que essa forma social amplia a capacidade de gerenciamento populacional no tempo e 
no espaço, desde que possa ser centralizada e direcionada por agentes intermediários. Dessa maneira, percebe-se o valor que pode tomar essa posição, uma vez que empresas (como visto acima, no caso da Alpop, mas não só) ou o Estado e outras instituições passam a acessar um universo antes fechado pela dinâmica popular dispersa - ganhando, portanto, capacidade gerencial. Importante aqui dar relevância à tendência de transformação do caráter político da liderança comunitária predominante no momento da redemocratização - baseado no conflito com a ordem social estabelecida que mantinha, e mantém, a exploração da comunidade - para essa face empreendedora. Não que essa face não exista antes, mas nos parece que ela ganha outro caráter e relevância maior do que tinha na medida em que se reestruturam as dinâmicas de acumulação e suas vinculações com o Estado.

A "viração" de Cleide na moradia, portanto, dá-se nas tramas entre a indução e mediação do poder público e a submissão às relações de poder locais que, na verdade, se assemelham apenas longinquamente com a organização comunitária. São, na prática, uma gestão privada e centralizada do território, cujo lastro é o domínio da dinâmica imobiliária (Alves, 2019). Cleide, no caso, está alugando atualmente um cômodo construído para essa finalidade, de maneira "empreendedora". Esta é uma prática relevante em territórios populares, principalmente em comunidades que tiveram partes removidas e beneficiadas com o Auxílio Aluguel em massa - havendo até casos relatados, nas entrevistas, de retenção do cartão do programa como fiança, uma das práticas de sujeição às quais nos referimos. Como vimos acima, não é possível construir sem mediação nos territórios populares - algo que fica explícito no seu relato, quando ela tenta autoconstruir na área de risco. Em São Paulo não conhecemos ainda indícios de práticas milicianas como no Rio de Janeiro, ${ }^{31}$ no entanto, há muitos elementos trazidos de campo que indicam algumas aproximações bastante particulares do território popular paulista, marcado pelo controle, por meio da violência, do mercado de terras. A generalização do aluguel no mercado popular, nesses termos, aciona uma dinâmica mais profunda de gestão de populações que, perpassada pelo Auxílio Aluguel como dispositivo de remoções e regulação imobiliária local, envolve também o poder público. É um estágio posterior à grilagem simples de terras. Vejamos isso por meio deste depoimento, de um beneficiário do Auxílio Aluguel da mesma comunidade que Cleide:

Depois disso fizeram três ou quatro vezes [barraco no córrego], e a prefeitura disse que não pagaria mais o auxílio. Gente de fora e de dentro, que na época tinha 15 anos e agora tem 23 e não tem solução. Não faz para receber auxílio, faz por necessidade mesmo. Agora as pessoas já não constroem não é porque sabem que não vai ganhar nada. Os moradores da comunidade é que não querem que tenha alguém no córrego. Outra coisa é a "família", né? Vem aí o Ednei e diz que não pode, que se construir vai começar aquela bagunça toda de novo. Não precisa nem desmanchar, porque não coloca nem a primeira madeira. A gente não deixa mais, porque vem muita gente de fora aí querer vender barraco aqui. $O$ "crime" não é assim não... tem todo um "debate", é um "vamos ver, com quem eu falo?". Cada comunidade tem o seu comandante, e ele respeita o que a comunidade quer. 
Na sua fala, mostra-se o embate entre o empreendedorismo popular, a reserva de terras feita pela administração da comunidade e as mediações veladas, muitas vezes, com o poder público: a nova situação de "não poder construir" também vem de negociação realizada entre secretaria de habitação e lideranças. Em entrevista realizada com o ex-secretário Fernando Chucre, ${ }^{32}$ ele disse ter dito, às lideranças de áreas reiteradamente removidas, que não daria mais o Auxílio Aluguel para novas ocupações, o que se efetivou com a alteração recente da portaria Sehab 131/2015, que define critérios de atendimento habitacional provisório. Veja-se que o empreendedorismo e "o que a comunidade quer" não são tão autônomos assim, sendo perpassados por uma gestão específica, centralizada, que envolve também o fundo público. É essa a face oculta do empreendedorismo, aparentemente o reino da liberdade, autonomia e criação de comunidade, que pode ganhar maior escala se essa centralização se conectar aos fundos de investimento, como visto acima.

Os regimes de gestão privada do território entram nessa chave, que pode ser ainda mais intensificada se tal "viração" habitacional puder ser produtiva para o capital. É o que prometem as transformações do lugar do aluguel na política pública, mediadas pelos interesses de um mercado de aluguel popular conectado aos fundos de investimento. Tais imobiliárias de plataforma digital podem colocar em andamento, na esfera da habitação, o que Abílio (2017) chamou de "subsunção real da viração" para os regimes de trabalho ditos "uberizados" que, ao centralizar o gerenciamento de uma mão de obra precarizada, mas "proprietária" - aqui, no caso, de moradias de aluguel no mercado popular -, tornam-na produtiva para circuitos de acumulação financeiros.

\section{Um novo papel do Estado}

O Auxílio Aluguel no município de São Paulo é paradigmático para o entendimento das possíveis novas formas de captura das dinâmicas habitacionais populares pelo mercado financeiro-imobiliário num futuro próximo, com mediação da política pública, como visto acima. Ao analisar essa realidade, parece-nos que a "viração" no mercado de trabalho induzida por mudanças macroestruturais não apenas influencia transformações nos modos de morar e nas dinâmicas territoriais, mas se apoia nelas. Pois o sujeito social forjado para a "viração" precisa ter seu modo de vida em permanente instabilidade para estar disponível ao grau de violência das relações de trabalho propostas - e a insegurança habitacional é parte fundamental disso. Interessa, aqui, que, bem como essas relações de trabalho precisam ser normatizadas pelo Estado, a insegurança habitacional também precisa ser construída e gerenciada institucionalmente, numa reconfiguração do papel estatal. Tal reconfiguração passa pela alteração na forma do direito social, que antes pressupunha a resposta material à necessidade concreta - hospital para a doença, escola para os jovens, casa para os sem-teto -, direcionando-se agora para o gerenciamento de demandas que possam ser remuneradas no mercado privado, de preferência de maneira financeirizada. 0 direito social à moradia definitiva parece não se adequar mais às necessidades do capital financeiro na periferia. Ele precisa se adaptar, abstraindo o que há de materialização qualitativa concreta na sua efetivação - a casa.

A partir do entendimento desse novo cenário nos parece relevante, para além dos mecanismos de circulação de capital envolvidos, procurar dar luz aos processos sociais que 
os estruturam, que envolvem a compreensão de novas subjetivações e formas de organização social e política diversas daquelas em que as relações da sociedade salarial e da propriedade privada configuravam o trabalhador organizado coletivamente em partidos, sindicatos e movimentos sociais centrados, no campo da habitação, na produção coletiva de espaço urbano e nas formas de morar próprias às prefigurações de transformação daquela sociedade. A ascensão do aluguel, aqui, não pode ser entendida, portanto, nos mesmos termos do aluguel social da sociedade salarial, lastreado em propriedade pública de um Estado interventor, que investe o fundo público diretamente na construção de novas unidades. São outros termos quando esse Estado se coloca como garantidor de direitos abstratos que, no caso da moradia, significa despojá-la de suas condicionantes materiais, subjetivas, culturais, sociais e políticas - causando uma transubstanciação do seu caráter de resposta à necessidade de vida humana em quantidade de tempo abstrato e remunerado (o pagamento de um valor mensal).

Os termos do debate sobre aluguel num contexto de desmonte estrutural das relações salariais em nível mundial precisam passar, portanto, pelo entendimento do papel do Estado como regulador público dos direitos privados - seja do trabalho, seja da moradia. Retomando historicamente essa relação a partir do uso do fundo público, vemos que, enquanto no período desenvolvimentista (década de 1970), tais direitos eram garantidos pela criação direta de vagas de trabalho (empresas e serviços públicos) ou moradias (BNH), durante o que foi chamado de "neodesenvolvimentismo" (gestões do PT no governo federal), eles foram induzidos ${ }^{33}$ - criando já uma alteração da anterior prerrogativa do interesse público sobre o privado (na moradia, o caso do Programa Minha Casa Minha Vida).

Tal interpretação desse período, no entanto, obscurece a especificidade do avanço e das transformações da lógica neoliberal em países periféricos que, de forma difusa durante a segunda metade da década de 2000, mas com força na década seguinte, tem ganhado espaço na ação estatal: amplia-se o lugar do direito privado ante o público (processo de privatização $)^{34}$ na mesma medida em que avança a conexão das dinâmicas econômicas entre setor público e finanças. Esse processo de privatização, portanto, tem especificidade histórica diferente daquela da década de 1990 (na qual havia passagem de propriedade de ativos estatais para o setor privado), relacionando-se agora com formas de securitização - de ativos, serviços e direitos, gerando mais um fluxo de rendimento do que uma transferência estática de ativos. Nessa lógica, perde espaço a dimensão pública do direito social (arena de disputa política) e ganha predominância a noção de direito liberal, no qual a mediação contratual privada assume papel de mediação social. ${ }^{35}$

Referimo-nos, aqui, à racionalidade própria às Parcerias Público-Privadas, mas não só, pois há outras formas de arranjos público- privados que passam por essa lógica - como outros tipos de concessões de serviços públicos ou parcerias específicas, ${ }^{36}$ que podem incluir o mercado de Impacto Social citado acima. São dinâmicas complementares de uma forma de financeirização dos serviços sociais que o Estado adquire tendencialmente, no caso da moradia:

\footnotetext{
Enquanto os SIBs ainda estão em estágio experimental, em termos de mercantilização/privatização dos serviços sociais, do ponto de vista das políticas públicas,
} 
eles representam uma fissura radical. As iniciativas tradicionais de privatização simplesmente oferecem aos investidores privados a oportunidade de prestar serviços ao Estado em troca de um pagamento garantido. [...] Os SIBs são, na prática, uma série de contratos de pagamento por resultados, nos quais os sem-teto são alvos de várias métricas de resultados de desempenho. De fato, os sem-teto se tornam mercadorias, na medida em que eles próprios têm o potencial de produzir fluxos de caixa futuros para os investidores. (Cooper, Graham e Himick, 2016, p. 3; tradução livre)

Se este é o caso dos países centrais, nos quais o processo de financeirização é mais avançado, no caso dos países periféricos tais formas de garantir direitos parecem estar disputando a noção de "direito social" (cara ao período de redemocratização das décadas de 1980 e 1990), sem prescindir dela: pois o fundo público pode garantir abstratamente sem efetivar concretamente o direito, ou seja, utiliza-se de maneira instrumental (apenas como meio) da necessidade concreta da população e da sua responsabilidade de garanti-la com uma finalidade diversa daquela que seria um fim público (a efetivação concreta da moradia digna, no nosso caso). Se a finalidade, na verdade, é o fluxo permanente de capital (como renda), tal efetivação concreta tem a tendência de tornar-se abstrata, no limite, fictícia (no caso da moradia, podendo ou não se transformar em casa real). 0 fundo público passou, portanto, com mais evidência (ao menos no urbano), desde a década de 2010, a ser cada vez mais disputado para a formação de fundos de investimento, denominados "fundos garantidores" ou, ainda, "fundos de securitização de recebíveis", de uma gama de relações público-privadas que pode possibilitar a transformação dos serviços públicos em setores rentáveis para capitais que ganham (financeiramente) com o alto risco representado pelo atendimento às classes populares.

Nesse novo modelo que tem entrado na disputa pela reforma do Estado, os direitos sociais são entendidos como propriedades de cada cidadão, que trazem consigo a potencialidade de ter de ser realizadas, necessariamente, por lei. Tal realização concreta pode ser efetivada de maneira privada e difusa, mas deve ser assegurada pelo monopólio estatal. Este pode ser transformado em gestão de fundos securitizadores (como o que está sendo proposto no PL 258/2016), que asseguram a realização do direito, portanto, de maneira abstrata, sem se comprometer com a forma qualitativa de sua materialização. 0 monopólio estatal de gestão de garantia de direitos é vinculado à dispersão privada de sua realização concreta, desenhando, assim, um modelo que, de um lado, intensifica as realizações privadas difusas e, de outro, centraliza sua remuneração - na medida em que o fundo público securitiza o risco dos pagamentos individuais. A forma do aluguel é propícia para isso, pois permite a desvinculação entre a materialização imediata das coisas (sua qualidade) e a gestão de seu usufruto: ele não significa menos propriedade, mas o monopólio de gestão e direcionamento das rendas de muitas propriedades que, juntas, colocam em andamento uma massa de valor maior do que poderiam se fossem de um único dono - a lógica própria aos fundos financeiros. Pois a força de trabalho que as faz render (que constrói cômodos de aluguel nos territórios populares) é também dispersa com elas, diminuindo os tempos ociosos de uma produção centralizada. Portanto, desenha-se uma 
configuração de realização do direito - como propriedade individual, direito subjetivo privado - intermitente, on demand, cuja métrica não é a necessidade de moradia, mas a da remuneração flutuante dos juros associados aos riscos de realização, no presente, de serviços securitizados no futuro pelo fundo público.

Dessa perspectiva, asseguram-se - securitizando - direitos, antes como gestão de demanda por meio de remuneração de mercado privado disperso e popular (com vários níveis de formalidade) do que como solução da necessidade material. Tal gestão, portanto, predomina sobre a produção, colocando novos elementos sociais e políticos no território popular.

\section{Securitização do direito à moradia no território popular}

Foram dez anos de muito - vou falar pra você - muito sufoco. Sem expectativa nenhuma, sem nenhuma resposta de quando você vai ter sua moradia. Você não pode comprar nada para a sua casa, você não pode fazer planejamento. $\mathrm{Na}$ verdade, você não pode fazer nada! Até a prefeitura ter a boa vontade de falar: 2000 e tal vai sair, tá aqui a chave da sua casa. Mas foi 10 anos de apuro, 3 casas de aluguel, tive que sair de uma e ir pra outra. E aí vai. Vamos tocando o barco desse jeito. ${ }^{37}$

A espera também mudou, deixou basicamente de ser um horizonte. Tornou-se, ao contrário, uma disciplina. [...] Uma tal disciplina da espera seria inerente ao regime de historicidade que caracteriza o momento atual da acumulação mundializada. (Arantes, 2014, p. 166
A partir dessas colocações, é possível agora retomar o mote inicial do texto, no qual lembrávamos que a tese sobre o desenvolvimento brasileiro de Francisco de Oliveira na década de 1970 se desenvolveu a partir da observação da centralidade da autoconstrução e da posse da terra na reprodução da força de trabalho do País, num contexto de consolidação das relações salariais. Seguindo o mesmo caminho, há de se pensar sobre as transformações da conjuntura social e política do País, decorrentes do desmanche das relações salariais, na qual ganha centralidade a forma social do aluguel: na habitação e no trabalho, o que está em jogo é a produtividade da intermitência, da insegurança, da captura de um tempo futuro que precisa ser vivido no presente, do direito relativizado e flexibilizado, da concorrência generalizada na busca de diferenciais (de localização ou de empregabilidade) - encarados como privilégios -, do empreendedorismo que desmonta relações de solidariedade de classe, da vida por um fio numa "era de expectativas decrescentes" (ibid.), expressa cabalmente aqui pela "fila da habitação" remunerada, mas, antes de mais nada, gerida pelo Auxílio Aluguel. Pois, antes de prover moradia, seu lugar é o de gerar um vínculo entre a "viração" do morar e a possibilidade permanente de punição institucionalizada - atualizada violentamente em "cortes" abruptos. ${ }^{38}$ É preciso notar que essa experiência, segundo Arantes, é já um processo de subjetivação, no qual

Fazer esperar e punir não só rimam no universo das disciplinas redescobertas por Foucault, mas sobretudo que fazer esperar já é punir, na exata medida que não se pune mais para corrigir um desvio, mas para agravar um estado indefinido de expiação e contenção. (Ibid., p. 150) 
Punição esta, como vista acima, ligada à necessária conformação de insegurança habitacional requerida pelos mercados financeiros, que alteram a forma do direito social. 0 que estamos vendo em relação às possibilidades de securitização ligadas ao Auxílio Aluguel parece fazer parte de um processo de aprofundamento perverso - e não negação - da legitimidade do direito social: ao não cumprir no presente o direito, este aparece como "dívida" social, fazendo com que o Estado, em seu papel de garantidor, passe a "assegurá-lo", 39 pagando juros sob a forma de aluguel - uma moradia "à prestação" baseada não na amortização do investimento passado (como na locação em parque público), mas em juros sobre capital (privado) adiantado. Essa forma de relação entre o público e o privado parece ser uma configuração histórica nova, que se expressa em todos os direitos sociais. Esse trecho de Catini, embora se refira à educação, parece-nos útil para pensarmos a questão da moradia, nos termos em que a discutimos acima:

Essa hipótese persegue a noção de que os direitos sociais são formas históricas e se alteram em função daquilo que ele é proveniente, que é a própria forma de realização da força de trabalho e a reprodução social de trabalhadores e trabalhadoras. Se num momento histórico que correspondia à consolidação de direitos públicos num Estado de bem-estar social que, como sabemos, nunca se efetivou plenamente nos países periféricos, a dissolução da sociedade industrial e salarial e as mudanças nas formas da exploração e contratos da força de trabalho alteram ainda mais as formas dos direitos sociais. No entanto, a privatização dos direitos sociais não se dá em detrimento do Estado ou de seu enfraquecimento, mas de seu fortalecimento como protetor dos direitos privados individuais. Não parece que se trata de um Estado Mínimo, mas de um Estado amplo que faz a gestão social em conjunto com empresas privadas e bancos - que não estão disputando com o Estado o controle da educação, mas concorrendo umas com as outras, enquanto o Estado é indutor e fiador desses novos contratos de prestação de serviços sociais. A hibridização de recursos públicos e privados para manutenção de serviços sociais indica essa simbiose entre o que é estatal e privado, mas perdem o caráter público que assumiram num momento específico da história. (Catini, 2019, s/p.; grifos nossos)

Nessa nova configuração gerencial do Estado, a não efetivação material no presente do direito à moradia não se resume, portanto, à "perda de direitos". Trata-se de reconfigurar sua forma social, transformando-o em dispositivo de acionamento de novas relações entre o público e o privado, capturando o universo popular. No caso da habitação, vemos que a defesa democrática do direito à moradia é mobilizada apenas como acionamento da política pública como instrumento de gestão de uma população que não acessará a casa - ou o fará apenas pontualmente, sem que isso altere a condição geral da política pública, que segue mantendo a condição de instabilidade de outras famílias, sempre repostas: a perspectiva é de uma massa de população permanente na espera gerenciada pela casa. Assim, a disciplina da espera - marca da subjetivação financeirizada, como nos coloca Arantes (2014) - é a expressão da gestão institucionalizada da "viração", um cotidiano de punição social. 
0 direito à moradia a se realizar no futuro, no presente, aparece como quantia abstrata - R\$400 que são a expressão do teto, mas podem não ser (e em essência não são). Essa questão é consequência do fato de que o instrumento opera uma espécie de transubstanciação da materialidade da moradia (existente antes da remoção) em uma quantia mensal abstrata que não carrega consigo nenhuma vinculação com a realidade concreta (seja territorial, habitacional ou do valor dos aluguéis existentes), mas apenas com um tempo indefinido de espera. Retira-se espaço, substituindo-o por tempo remunerado com vistas à materialidade futura da moradia - que, no presente, é "viração" perpétua, ou seja, está fadada a um futuro fictício que se apresenta apenas como submissão aos mercados populares.

Quando o município baseia sua ação no desconhecimento consciente sobre a maneira como se dá qualitativamente a moradia, transformando-a em quantia abstrata, também se abstém de assegurar sua concretude estável. De um lado, ele ganha capacidade de expansão "absoluta" de espaço institucionalizado, ganhando território extensivo ao remover sua ocupação concreta, que é transformada em tempo de espera sem materialidade. De outro, muda o caráter mesmo da sua função pública "garantidora" do direito social: agora ela se dá por meio do sujeito jurídico abstrato (Pachukanis, 1988) e não da noção de cidadania, ou seja, perde a vinculação com a satisfação de necessidades imediatas e, também, com a dimensão coletiva do direito universal. Mas o ponto é que o direito social continua sendo mobilizado. Ele não é recusado, ao contrário, parece ser o instrumento por meio do qual é possível essa "transubstanciação", que é geradora de uma nova dinâmica não mais baseada na efetivação da concretude do direito, mas na manutenção da sua impossibilidade como gestão de expectativas. Trata-se de uma mudança da noção de seguridade, que transita do ambiente estável das relações salariais (que podem ser planejadas) para aquele da gestão de populações, no qual a instabilidade da competitividade - no limite, da guerra social - é aquela que gera diferenciais necessários para a acumulação.

Assim, queremos olhar para o Auxílio Aluguel e suas prováveis futuras novas formas institucionais como uma expressão de um novo Estado, que precisa assegurar direitos sem efetivá-los concretamente - a não ser de maneira intermitente - para uma massa de expropriados tomados como sujeitos abstratos. Essa passagem se dá por meio da qualidade abstrata do Auxílio Aluguel como direito subjetivo "assegurado" no presente, cuja forma social é paralela à da "securitização", na medida em que é um terceiro (de caráter privado) que adianta a moradia de maneira transitória e remunerada. O mecanismo que parece operar aqui é uma espécie de securitização de direitos que, se efetivada institucionalmente, inaugura uma fase avançada do direito social (e não sua negação), que pode ser pensada como de sua subsunção real (Marx, 1978) à forma social do capital fictício. Não se trata de privatização, da perspectiva de transformação do direito em pura mercadoria intercambiável, como defendeu a ideologia neoliberal da década de 1990, tendo em vista uma diminuição do Estado - o que seria um retrocesso. É, na verdade, um desenvolvimento desse modelo, no qual há uma ampliação do Estado de Direito como garantidor, utilizando mecanismos próprios à lógica do capital portador de juros. Assim, a moradia transformada em serviço por meio do aluguel dá a ela 
a capacidade de entrada num meio ao mesmo tempo mais próximo ao direito social do que ao puro direito privado (de acesso à propriedade), mas, por isso mesmo, também mais próximo à vanguarda da frente de acumulação do capital nos países periféricos, atualmente.

O acesso a certos bens e serviços não é mais considerado ligado a um status que abre portas para direitos, mas o resultado de uma transação entre um subsídio e um comportamento esperado ou um custo direto para o usuário. A figura do "cidadão" investido de uma responsabilidade coletiva desaparece pouco a pouco e dá lugar ao homem empreendedor. Este não é apenas o "consumidor soberano" da retórica neoliberal, mas o sujeito ao qual a sociedade não deve nada, aquele que "tem que se esforçar para conseguir o que quer" e deve "trabalhar mais para ganhar mais", para retomarmos alguns dos clichês do novo modo de governo. A referência da ação pública não é mais o sujeito de direitos, mas um ator autoempreendedor que faz os mais variados contratos privados com outros atores autoempreendedores. Dessa forma, os modos de transação negociados caso a caso para "resolver os problemas" tendem a substituir as regras de direito público e os processos de decisão política legitimados pelo sufrágio universal. Longe de ser "neutra", a reforma gerencial da ação pública atenta diretamente com a lógica democrática da cidadania social; reforçando as desigualdades sociais na distribuição dos auxílios e no acesso aos recursos em matéria de emprego, saúde e educação, ela reforça as lógicas sociais de exclusão que fabricam um número crescente de "subcidadãos" e “não cidadãos. (Dardot e Laval, 2016, pp. 380-381)

No caso da moradia em país periférico, a gestão da insegurança habitacional - como pode ser chamada essa "securitização" do direito - dá-se necessariamente através da flexibilização do mercado imobiliário residencial direcionado para essa "população excedente". Ele precisa se livrar das formas sólidas de propriedade e adentrar no campo difuso das práticas populares relacionadas à moradia, cuja instabilidade - gerenciada por regimes privados locais - lastreia a necessidade de mobilização de fundos de securitização públicos ou privados, como vimos acima. A forma do aluguel é propícia para isso, na medida em que desvincula uso e propriedade, sendo um instrumento possível de conexão entre as formas de morar populares e a esfera de circulação do capital imobiliário. 0 que faltava nessa equação era a possibilidade de centralização de direcionamento das rendas, o que pode, em breve, ser realizado por meio da política pública, como já visto. Inicia-se, assim, um regime de direito ligado à "usabilidade", e não à "habitabilidade", como foi um dia a bandeira do direito à moradia.

\section{[I] https://orcid.org/0000-0001-7400-0642}

Universidade de São Paulo, Faculdade de Arquitetura e Urbanismo, Departamento de Projeto. São Paulo, SP/Brasil.

isaguerreiro@uol.com.br 


\section{Notas}

(1) Importante diferenciar a noção de trabalho como atividade criativa, ligada à transformação qualitativa do mundo, "trabalho em geral" ou, ainda, trabalho "subsumido formalmente" ao capital, da noção de "trabalho abstrato subsumido realmente ao capital", ao qual a noção de emprego (da força de trabalho) talvez seja mais próxima (cf. Marx, 1978).

(2) "[...] O fato é que a orientação espaço-temporal do capitalismo mudou de rumo e ingressou noutra dimensão da experiência da história, ou num novo regime de historicidade, como preferem dizer alguns historiadores, que não por acaso se identificam como historiadores do presente, sendo que esse novo regime da experiência social do tempo se caracteriza por essa inédita, se é que se pode falar assim, onipresença do presente (Hartog, 2003), que todos estão chamando genericamente de Presentismo, deslizando de todo modo ao longo do eixo da aceleração e da urgência" (Arantes, 2014, p. 165; grifos no original).

(3) “E aí se chega ao seguinte paradoxo: não se cria um mercado imobiliário. Mercado imobiliário no Brasil só existe da classe média para cima. Nas classes populares, não existe. É impossível existir, porque você está de posse exatamente daquilo que não é mercadoria. A casa não pode ser trocada, não tem valor de troca, tem apenas valor de uso, a finalidade de habitar" (Oliveira, 2006, p. 72).

(4) O direito social, aqui, pode ser entendido como aquele que transpassa o direito público e o direito privado de maneira horizontal (Batista, 2013), buscando a satisfação da necessidade do sujeito de direito (direito subjetivo, privado) pela efetivação do serviço de necessidade básica como política pública (que pode ser efetivada pelo setor privado). O caráter de direito subjetivo subjacente ao direito social tem a particularidade de ter o Estado (o direito público) como fiador - aquele que deve fazer cumprir o direito por meio do serviço, empenhando, para isso, o fundo público.

(5) Disponível em <https://www.prefeitura.sp.gov.br/cidade/secretarias/upload/PMH_2016(1).pdf>. Acesso em: $13 \mathrm{fev}$. O PMH ainda não foi aprovado até a presente data.

(6) Tal programa já passou por diversas regulamentações, tendo iniciado como Bolsa Aluguel na gestão de Marta Suplicy em 2004. O atual Auxílio Aluguel faz parte do Programa Ações de Habitação (decreto n. 51.653, de 22 de julho de 2010), regulamentado pela portaria Sehab 131/2015. Alterações nessa portaria retiraram, em 2019, o atendimento à extrema vulnerabilidade do programa.

(7) Os dados flutuam mês a mês, mas têm permanecido nesse patamar desde 2017. A listagem atualizada dos beneficiários pode ser visualizada em <http://www.habitasampa.inf.br/ atendimento/consulta-de-atendimentos-em-andamento-ou-encerrados/atendimentoprovisorio-auxilio-aluguel/>; acesso em: 17 fev 2020. 
(8) Entrevista realizada em 8 de fevereiro de 2020 com beneficiários do Auxílio Aluguel removidos de área de risco.

(9) Disponível em: <http://www.labcidade.fau.usp.br/crise-habitacional-em-sp-estamos-diante-deuma-maquina-de-despejos-e-remocoes/>. Acesso em: 17 set 2019.

(10) Disponível em: <https://www1.folha.uol.com.br/cotidiano/2019/09/hiperverticalizacao-chega-afavelas-de-sao-paulo-onde-lajes-se-sobrepoem.shtml?loggedpaywall>. Acesso em: 17 set 2019.

(11) A pesquisa foi realizada em conjunto pelos Laboratórios Quapá e Napplac, tendo como responsáveis João F. P. Meyer, Emilio Haddad, Maria de L. Zuquim, Caio S. A. de Carvalho, Ângela L. Barbon, Ariadne P. Silva, Gustavo M. dos Santos e Rodrigo Minoru. Financiamento do Lincoln Institute of Land Policy.

(12) Pesquisa "Favela e Mercado Informal: a nova porta de entrada dos pobres nas cidades brasileiras" (Abramo, 2009). Rede Infosolo: UFRJ, USP, UFBA, UFRGS, UFPA, UFSC, UFPE, UNB. Pesquisa financiada pela Finep, coordenada pelo professor Pedro Abramo (UFRJ).

(13) Rentabilidade do aluguel em relação ao valor do imóvel.

(14) Enquanto em Paraisópolis se alcançava 1,32\% de rentabilidade no aluguel para apartamentos de 1 dormitório, em São Paulo a média era de 0,46\% no mesmo período (2016).

(15) Entrevista realizada em 20 de junho de 2019 com beneficiários de mais de 10 anos do Auxílio Aluguel.

(16) "Saiu" quer dizer que houve remoção da área.

(17) "Peguei" quer dizer que recebeu um benefício da prefeitura para sair da área na forma de quantia fixa, o conhecido coloquialmente como "cheque-despejo".

(18) A área era dividida em duas matrículas, uma de propriedade particular e outra pública.

(19) Entrevista realizada em 8 de fevereiro de 2020 com beneficiários do Auxílio Aluguel removidos de área de risco.

(20) Em referência à possibilidade de interrupção do benefício do Auxílio Aluguel.

(21) Disponível em: <https://www.alpop.com.br/>; acesso em: 22 fev 2020.

(22) O Instituto Urbem tem atuação em grandes projetos urbanos, em particular aqueles que envolvem a relação público-privada. Dentre seus trabalhos, destacam-se: maior parte da modelagem da Parceria Público-Privada (PPP) habitacional Casa Paulista; modelagem do projeto de reestruturação urbana Arco-Tietê (São Paulo); Projeto de Intervenção Urbana (PIU) Vila Leopoldina/Villa-Lobos (São Paulo). Disponível em: <https://www.urbem.org.br/>; acesso em: 23 ago 2019.

(23) A Caiena é uma empresa de Design de Tecnologia que trabalha com big-data e softwares de interface de cidadania, por meio de novos conceitos, como o Design Thinking e Metadesign. Disponível em: <https://www.caiena.net/\#home>; acesso em: 23 ago 2019. 
(24) A Arap Nishi \& Uyeda Advogados é especializada em "Modelagem de projetos de infraestrutura, direito administrativo, orçamento público e regulatório nas áreas de transportes, saneamento, energia, gás e petróleo, telecomunicações e mineração", mas também "Assessoria em operações societárias (fusões e aquisições, transações de private equity, incorporações, investimento estrangeiro, reorganizações societárias, joint ventures), auditoria legal, governança corporativa, compliance", "Financiamentos bancários em projetos de infraestrutura, operações imobiliárias, project e corporate finance, estruturação de fundos de investimento" e "Estruturação de operações imobiliárias, projetos de regularização fundiária e implantação de projetos de infraestrutura". Disponível em: <http://arapnishi.com.br/>; acesso em: 23 ago 2019.

(25) Entrevista realizada em 14 de março de 2019.

(26) Segundo João Chiavone, em cuja pesquisa me baseio para essas informações sobre Impacto Social, no mundo "o volume de emissões de Títulos Sociais cresceu muito nos últimos anos, passando de US\$2,8 bilhões em 2016 para US\$14 bilhões em 2018 (aumento de 71\%)" (Chiavone, 2020, p. 12).

(27) O veto ao projeto foi justificado, entre outros motivos, pela falta de delimitação da categoria de Habitação de Interesse Social, além de criar oneração excessiva ao erário público - sem citar problemas relacionados à inserção de dinâmica financeiro-imobiliária no programa.

(28) Entrevista realizada no dia 3 de abril de 2019.

(29) Cleide (nome fictício), em entrevista realizada em 20 de junho de 2019 com beneficiários há mais de 10 anos do Auxílio Aluguel.

(30) Encontramos outras lideranças com funções parecidas nas comunidades que fizemos entrevistas: foi por meio delas que chegamos aos beneficiários do Auxílio Aluguel entrevistados (o que seria inviável pelo cadastro público, que não tem informação do local de moradia alugada e protege as identidades dos beneficiários), o que já demonstra bastante do seu papel de elo entre a dinâmica popular e as instituições (no nosso caso, a universidade).

(31) Segundo o sociólogo José Cláudio Souza Alves (2019), as milícias cariocas são grupos que articulam o uso da violência no território ao acionamento de agentes do Estado, dominando o mercado das comunidades desde as transações de terra até os serviços urbanos, passando pela produção do espaço.

(32) Entrevista realizada no dia 3 de abril de 2019.

(33) "Enquanto para o velho desenvolvimentismo o Estado devia ser também produtor, porque o setor privado não tinha capacidade de investir, hoje, no quadro do novo desenvolvimentismo, em um país que já realizou sua revolução capitalista, o papel do Estado na área econômica deve ser apenas estratégico ou indutor" (Bresser-Pereira, 2011; grifos nossos).

(34) "O aumento dessas garantias estaria intimamente ligado ao aumento da confiança para participação do setor privado e no financiamento de projetos de infraestrutura nacional. A nosso ver, esse necessário aumento de confiança para participação do setor passa pelo afastamento das decisões sobre projetos de transformação urbana da esfera das decisões negociadas no âmbito político. Isso representa uma das importantes dimensões da reforma do Estado em curso que é a privatização, não apenas de ativos públicos, mas, também, de competências de gestão, inclusive sobre os processos decisórios, antes exclusivos do Estado, dando maior controle ao setor privado sobre a implantação de projetos urbanos em detrimento de processos públicos e democráticos" (Nascimento et al., 2018, p. 16). 
(35) Para maior aprofundamento na forma jurídica que assume o direito subsumido ao capital, ver Pachukanis (1988).

(36) Os Projetos de Intervenção Urbana (PIU), aprovados no âmbito do Plano Diretor Estratégico de São Paulo, são exemplos desse modelo. Há também casos em outras áreas, como na educação, na assistência social e na saúde, principalmente junto às Organizações Sociais.

(37) Entrevista realizada em 20 de junho de 2019 com beneficiários de mais de 10 anos do Auxílio Aluguel.

(38) Recentemente, a Secretaria de Habitação de São Paulo cortou, sem provas de inadequação e sem aviso prévio, cerca de 5 mil benefícios (ação barrada depois na justiça).

(39) O processo jurídico-financeiro de "securitização" (do inglês security), no qual se transforma em título financeiro uma dívida, baseia-se na relação social de "assegurar" ou tornar seguro seu pagamento futuro por meio de transferência de parcelas de juros sobre esse capital a um terceiro, que adianta, no presente, a quitação.

\section{Referências}

ABÍLIO, L. C. (2017). Uberização do trabalho: subsunção real da viração. Disponível em: https:// passapalavra.info/2017/02/110685/. Acesso em: 22 fev 2020.

ABRAMO, P. (2009). Favela e mercado informal: a nova porta de entrada dos pobres nas cidades brasileiras. Porto Alegre, Finep.

ALVES, J. C. S. (2019). No Rio de Janeiro a milícia não é um poder paralelo. É o Estado. Disponível em: https://apublica.org/2019/01/no-rio-de-janeiro-a-milicia-nao-e-um-poder-paralelo-e-oestado/. Acesso em: 22 fev 2020.

ARANTES, P. (2014). O novo tempo do mundo. São Paulo, Boitempo

BATISTA, F. R. (2013). Crítica da tecnologia dos direitos sociais. São Paulo, Outras Expressões, Dobra Editorial.

BONDUKI, N.; ROLNIK, R. (1982). "Periferia da Grande São Paulo: reprodução do espaço como expediente de reprodução da força de trabalho". In: MARICATO, E. (org.). A produção capitalista da casa (e da cidade) no Brasil industrial. São Paulo, Alfa-ômega.

BRESSER-PEREIRA, L. C (2011). O Brasil e o Novo Desenvolvimentismo. Revista Interesse Nacional, ano 4, n. 13.

CATINI, C. (2019). Educação: revelação de mais uma face da financeirização e privatização dos direitos sociais. Disponível em: http://www.ihuonline.unisinos.br/artigo/7621-educacao-revelacao-demais-uma-face-da-financeirizacao-e-privatizacao-dos-direitos-sociais. Acesso em: 22 fev 2020. 
CHIAVONE, J. A. (2020). Recursos associados ao mercado financeiro para projetos habitacionais de impacto social. Dissertação de mestrado. São Paulo, Universidade de São Paulo.

COOPER, C.; GRAHAM, C.; HIMICK, D. (2016). Social impact bonds: The securitization of the homeless. Accounting, Organizations and Society, v. 55, pp. 63-82.

DARDOT, P; LAVAL, C. (2016). A nova razão do mundo: ensaio sobre a sociedade neoliberal. São Paulo, Boitempo.

FELTRAN, G. S. (2011). Fronteiras de tensão: um estudo sobre política e violência nas periferias de São Paulo. São Paulo, Editora Unesp.

FIPE. Índice FipeZap de Preços de Imóveis Anunciados. Disponível em: http://downloads.fipe.org.br/ indices/fipezap/dados-fipezap-202003-completo.xlsx. Acesso em: 16 set 2019.

FOUCAULT, M. (2010). Em defesa da sociedade: Curso no Collège de France (1975-1976). São Paulo, WMF Martins Fontes.

FRANK, A. G. (1967). El desarrollo del subdesarrollo. Revista Pensamiento Crítico. Havana, v. 1, n. 7, pp. 159-172.

GUERREIRO, I. A. (2017). A produção do espaço urbano pelo Lulismo: contradições específicas da dependência. In: XVII ENANPUR. Anais... São Paulo, Anpur.

HARTOG, F. (2003). Régimes d'historicité: présentisme et expériences du temps. Paris, Seuil.

IBGE (IPCA - Índice Nacional de Preços ao Consumidor Amplo). Disponível em: <https://www.ibge.gov. br/estatisticas/economicas/precos-e-custos/9256-indice-nacional-de-precos-ao-consumidoramplo.html?=\&t=series-historicas $>$. Acesso em: 16 set 2019.

KOWARICK, L. (1979). A espoliação urbana. São Paulo, Paz e Terra.

MARINI, R. M. (2005). “Dialética da Dependência”. In: TRASPADINI, R.; STEDILE, J. P. (orgs.). Ruy Mauro Marini: vida e obra. São Paulo, Expressão Popular.

MARX, K. (1978). Livro I Capítulo VI (Inédito). São Paulo, Livraria Editora Ciências Humanas.

MEYER, J. F. P.; HADDAD, E.; ZUQUIM, M. de L.; CARVALHO, C. S. A. de; BARBON, A. L.; SILVA, A. P.; SANTOS, G. M. dos; MINORU, R. (2017). Mercado imobiliário residencial em Paraisópolis: o que mudou nos últimos dez anos? Relatório de pesquisa. São Paulo, FAUUSP e Lincoln Institute of Land Policy.

NASCIMENTO, D. M.; ROMEIRO, P.; ROSA, S. V.; MOURA, R. C.; FRANZONI, J. A.; MENDONÇA, P. (2018). "O mecanismo da Parceria Público-Privada como reforma do Estado". In: ROLNIK, R. et al. (orgs.). Cidade Estado Capital: reestruturação urbana e resistência em Belo Horizonte, Fortaleza e São Paulo. São Paulo, FAUUSP.

OLIVEIRA, F. de (1988). Surgimento do antivalor: capital, força de trabalho e fundo público. Revista Novos Estudos Cebrap. São Paulo, n. 22, pp. 8-28.

(2003). Crítica à Razão Dualista e O Ornitorrinco. São Paulo, Boitempo.

(2006). O vício da virtude: Autoconstrução e acumulação capitalista no Brasil. Revista Novos Estudos Cebrap. São Paulo, n. 74, pp. 67-85. 
PACHUKANIS, E. B. (1988). Teoria Geral do Direito e Marxismo. São Paulo, Acadêmica.

ROLNIK, R. (2019). Guerra dos lugares: a colonização da terra e da moradia na era das finanças. São Paulo, Boitempo.

TELLES, V. da S. (2006). Mutações do trabalho e experiência urbana. Tempo Social: Revista de Sociologia da USP. São Paulo, v. 18, n. 1, pp. 173-195.

Texto recebido em $1 \% / \mathrm{mar} / 2020$

Texto aprovado em 19/abr/2020 